\title{
Value Creation dengan Penerapan Prinsip-Prinsip Lean Manufacturing dalam Accounting
}

\author{
Rina Nopianti \\ Universitas Bina Bangsa \\ Serang, Indonesia \\ rina.nopianti@binabangsa.ac.id \\ Andreas Tri Panudju \\ Universitas Bina Bangsa \\ Serang, Indonesia \\ ahmad.andreas@binabangsa.ac.id
}

\author{
Umi Marfuah \\ Universitas Muhammadiyah \\ Jakarta, Indonesia \\ umi.marfuah@ftumj.ac.id
}

\begin{abstract}
In many cases, some conventional accounting practices are no longer compatible with the complex manufacturing environment. The proposed this research is to inspire a systems thinking theory and a value chain management, building a business model that prioritizes customers. The objective of this paper is to find out how accounting techniques can optimize of resource utilization wihich would lead in creating value. The second objective is to minimize the lack of conventional accounting using the accounting method that appears.

The method in this shis paper is a qualitative research by considering the inductive method designed as a single case study.

Empirical data is used based on classic single case control studies that embedded designs including survey data, academic papers theoretical reviews, data collection from interviews, annual reports and documents collected from case companies.

The research found that the management accounting system could be integrated in the framework of Just in Time (JIT) + Total Cost (TC) + Time Driven-Activity Based Costing (TD-ABC) + Balance Scorecard (BSC) to develop lean accounting. The utilization of resource is optimized after nonvalue added activities are eliminated.
\end{abstract}

Keywords: lean accounting, lean manufacturing, value chain.

\section{PENDAHULUAN}

Dalam dunia persaingan globalisasi saat ini organisasi terus memutuskan untuk menggunakan metode dan alat baru, yang memungkinkan mereka untuk mengatasi ketidakpastian dan perkembangan yang akan dating (Almaryani \& Sadik, 2012). Sistem akuntansi manajemen dianggap sebagai salah satu mekanisme kontrol manajemen yang paling penting yang dapat mendukung pengambilan keputusan dan proses pengendalian organisasi. Berdasarkan strategi yang tepat, organisasi dapat mencapai tujuannya dan berhasil bersaing di pasar melalui keputusan yang efektif. Dengan demikian, manajer menggunakan informasi akuntansi manajemen yang relevan untuk mendukung diri mereka sendiri dalam perencanaan, pengendalian, evaluasi kinerja dan terutama membuat keputusan rasional untuk mengurangi biaya, meningkatkan kualitas produk dan kemudian mencapai tujuan jangka panjang organisasi, dengan penerapan beberapa metode akuntansi di lapangan. akuntansi manajemen strategis, seperti analisis rantai nilai, biaya berbasis aktivitas, pembandingan, balanced scorecard, dll (Almaryani \& Sadik, 2012; Medeiros \& Guimarães, 2017).

Lean management diperkenalkan oleh Ford Motors, AS, yang kemudian disempurnakan oleh Taiichi Ohno di Toyota Production System (TPS) di Jepang sekitar tahun 1980an. Lean accounting berfokus pada pengintegrasian serangkaian prinsip dan praktik manajemen, seperti Total Quality Management, Activity Based Costing - based time, just-in-time dan target costing, yang bertujuan untuk mengurangi biaya dalam proses penciptaan nilai melalui minimalisasi pemborosan dan penyederhanaan dari semua tahapan proses manufaktur (Manzouri, Abrahman, Che Mohd Zain, \& Jamsari, 2014; 
Medeiros \& Guimarães, 2017; Ramezani \& Branch, 2016).

Tujuan dari makalah ini adalah untuk mencari bagaimana teknik akuntansi dapat mendukung optimalisasi pemanfaatan sumber daya yang terarah untuk menciptakan nilai bagi organisasi yang menghubungkan teknik akuntansi manajemen kontemporer bersamasama.

\section{KAJIAN TEORI}

\section{Traditional Management Accounting.}

Sistem akuntansi manajemen tradisional tidak cukup untuk beradaptasi dengan perubahan dalam persaingan yang ketat dan tidak sesuai untuk lingkungan saat ini, terutama ketika beroperasi di lingkungan yang lean. Menurut Kaplan dan Anderson (2013), Romney and Steinbart (2015), kekurangan ini dapat disintesis sebagai berikut:

- Akuntansi tradisional biasanya mengalokasikan overhead produksi tetap berdasarkan jam kerja, meskipun otomatisasi, pemasangan peralatan terbarukan telah mampu secara drastis mengurangi jumlah tenaga kerja langsung yang digunakan untuk memproduksi suatu produk (Romney dan Steinbart, 2015). Dengan demikian, dalam teknologi yang digerakkan oleh teknologi, mesin dan peralatan intensif, alokasi biaya overhead berdasarkan tenaga kerja, tidak lagi dapat dibenarkan (Kaplan dan Anderson, 2013).

- Sistem akuntansi tradisional menggunakan biaya standar untuk menghitung biaya produk. Hal ini benar-benar mengabaikan biaya non-manufaktur atau biaya periode, dan biaya tersebut biasanya diperkirakan berdasarkan biaya historis yang telah dikeluarkan. Itulah sebabnya, biaya produk standar dapat menyesatkan ketika membuat keputusan yang terkait dengan profitabilitas, membuat atau membeli, penentua sumber daya, bauran produk, prioritas pelanggan, dll. Biaya standar yang dirancang selama tahun 1900 tidak lagi mencerminkan realitas ekonomi (Kaplan dan Anderson, 2013 ).

- Sistem produksi tradisional didasarkan pada perkiraan penjualan yang mengikuti pendekatan push yang mentransfer bahan mentah melalui sistem konversi sehingga produk akan siap untuk mengangkut ketika pesanan pelanggan tiba.

- Romney dan Steinbart (2015) berpendapat bahwa akuntansi tradisional lebih terfokus pada pemegang saham dan instansi pemerintah karena mengatur data akuntansi keuangan, yang didasarkan pada standar dan kepatuhan SAK undangundang perpajakan dan peraturan. Sedangkan penciptaan nilai didorong oleh pelanggan pada awalnya, lebih lanjut oleh karyawan dan pemasok di organisasi yang berorientasi laba.

- Sistem akuntansi biaya tidak memberikan ukuran yang mengukur pengaruh peningkatan kualitas sebagai laporan kinerja yang difokuskan pada ukuran finansial. Romney dan Steinbart (2015) menyatakan bahwa karyawan front-line, manajer lapangan, dan orang nonkeuangan membutuhkan informasi yang lebih akurat dan tepat waktu mengenai aktivitas fisik, seperti unit yang diproduksi, tingkat cacat dan waktu produksi. Dengan demikian, hal tersebut mengungkapkan hasil kuantitatif, namun bukan indikator kualitatif dari kinerja.

- Kinerja Kompetitor. Organisasiorganisasi kelas dunia memiliki tujuan untuk meningkatkan kinerja aktual pada tingkat yang lebih cepat daripada pesaing, tetapi akuntansi tradisional hanya membandingkan kinerja internal.

Beberapa peneliti berpendapat bahwa kekurangan akuntansi tradisional adalah sebagai berikut:

- Kurang terlibat kurang dengan operasi atau proses manufaktur, personil dan fungsi;

- Ini hanya mencakup rantai nilai internal ketika optimalisasi biaya melalui konfigurasi ulang rantai nilai tetap berada dalam lingkup rantai pasokan dari sisi pemasok serta di saluran distribusi di sisi pelanggan;

- Beban kerja yang signifikan pada karyawan keuangan dan operasional membutuhkan sejumlah besar kegiatan non-nilai tambah yang harus dilakukan oleh akuntan.

Lean accounting. Karena globalisasi pasar dan kemajuan teknologi dalam produksi dan operasi semakin meningkat dari waktu ke 
waktu, pendekatan baru (yaitu lean manufacturing, total kualitas manajemen (TQM), just in time (JIT), six sigma, kaizen dan target costing models) berhubungan dengan peningkatan berkelanjutan. efektivitas operasional yang kompleks untuk mengatasi daya saing (Ofileanu, 2015). Model lean adalah sistem hidup yang menghubungkan konsep-konsep untuk hidup selaras dengan keberlanjutan untuk memastikan kemungkinan bahwa semua kehidupan di bumi akan berkembang tanpa batas (Nasiri and Peláez, 2012).

Pesanan pelanggan memicu produksi dalam lean environment, sehingga pesanan pembelian dan penyimpanan inventaris saling bereaksi dan penjadwalan pesanan kerja sesuai dengan persyaratan pesanan pelanggan. Ini menunjukkan implikasi pendekatan Just in Time.

Sumber daya diselaraskan di sekitar aliran nilai untuk memberikan produk dan layanan kepada pelanggan yang membenarkan nilai untuk uang dengan kualitas, nuansa, dan fungsionalitas superior. Contohnya adalah penelitian desain logistik di industri Italia (Filippini \& Forza, 2016), di mana tercatat bahwa akuntansi lean berlaku untuk perusahaan manufaktur dan jasa. Konsep lean adalah filosofi di mana kegiatan-kegiatan yang tidak bernilai tambah dikenali dan dihilangkan dalam sistem lean manufacturing (Monroy, Nasiri \& Peláez, 2012).

Dalam lean, peningkatan berkelanjutan berarti pengurangan penundaan yang berfokus pada 'waktu' yang dapat mengurangi waktu tunggu, mempersingkat total waktu produksi, dan mengurangi waktu pengiriman pelanggan. Pengendalian waktu untuk memantau kapasitas yang tidak digunakan akan mengubah penghematan waktu sebagai pengurangan biaya. Ini menyiratkan pentingnya menerapkan Time Driven Activity Based Costing (Filippini \& Forza, 2016).

\section{METODOLOGI PENELITIAN}

Sesuai dengan tujuan penelitian ini, adalah untuk menganalisis teknik akuntansi manajemen dalam konteks waktu dan value chain, maka dipilihlah desain penelitian studi kasus. Penelitian ini didasarkan pada studi kasus tunggal, dengan menyajikan analisis kuantitatif data yang dikumpulkan dari survei. Tingkat analisis difokuskan pada organisasi, termasuk mewawancarai personel di perusahaan yang diteliti.

Dalam hal pengumpulan data, data dikumpulkan dari berbagai sumber seperti berbagai literatur, data survei, dan data yang dikumpulkan dari perusahaan kasus untuk membuat landasan temuan menjadi lebih andal dan valid.

Data survei digunakan untuk menyampaikan pendekatan penelitian yang menganalisis praktik terkini dari akuntansi tradisional serta penerapan teknik akuntansi modern. Tujuannya adalah untuk mengumpulkan informasi dalam pencarian arah untuk solusi yang mungkin dari perspektif profesional.

Perusahaan yang diteliti berkantor pusat di Singapura, dan memiliki beberapa perusahaan yang beroperasi di beberapa negara, salah satunya di wilayah Indonesia. Perusahaan ini bergerak di bidang periklanan, consumer goods dan yang terkait dengan penggunaan teknologi tinggi.

\section{HASIL DAN PEMBAHASAN}

\section{Analisis Data Survei Tentang Praktik Akuntansi Manajemen.}

Data survei dikumpulkan dari para akuntan profesional untuk membentuk pemahaman praktik akuntansi manajemen pada sistem kontrol manajemen sebagai titik awal penelitian. Data yang terkumpul dan dianalisis sebanyak 20 tanggapan dari para profesional yang terlatih.

Terlepas dari kritik dalam sistem akuntansi tradisional tentang kekurangannya seperti distorsi alokasi overhead produksi, bufferstock, kepasifan para pemegang saham dan sebagainya (Romney \& Steinbart, 2015), survei empiris mencerminkan bahwa akuntansi konvensional masih dominan dipraktikkan. Misalnya, teknik anggaran dan prakiraan mendapatkan tingkat adopsi tertinggi $(60 \%)$, diikuti oleh analisis tertinggi kedua $(45 \%)$ dan kemudian setelah teknik penilaian investasi $(30 \%)$ dengan menggunakan NPV dan periode pengembalian. Sebaliknya, pendekatan target costing (45\%) menempati tingkat pertama 
dalam popularitas penggunaan alat akuntansi manajemen kontemporer, kemudian diikuti JIT sebesar 35\%, dan ketiga, Balanced Scorecard (30\%).

Alat dan teknik akuntansi sebagian besar digunakan untuk melaporkan production cost (73\%), profitabilitas $(67 \%)$, processing cost (47\%), activity cost $(40 \%)$ dan biaya benchmarking (40\%). Oleh karena itu, sejalan dengan gagasan Monroy dkk. (2012) bahwa kemungkinan penerapan lean accounting, pengintegrasian balanced scorecard dan activity based costing dapat diimplementasikan sebagai teknik kontemporer yang dapat membuat laporanlaporan tersebut lebih efisien dan akurat.

Penggunaan ERP yang mengintegrasikan rantai pasokan, manufaktur, operasi, sumber daya manusia, penjualan, layanan pelanggan dinyatkan oleh kurang lebih $90 \%$ responden. Hal ini mengungkapkan pentingnya implikasi otomatisasi teknologi informasi dan integrasinya dalam fungsi akuntansi. Dengan demikian, sistem harus sangat adaptif dan fleksibel karena ERP harus mengelola perubahan dengan cepat untuk mendukung strategi keuangan dan operasional perusahaan

\section{Sistem Akuntansi}

Karena semua perusahaan operasi memiliki sistem akuntansi, Microsoft Business Dynamics Navision yang memungkinkan perusahaan menghasilkan laporan dalam jangka waktu yang yang telah disesuaikan dalam kalender pelaporan setiap tahun untuk melaporkan informasi keuangan yang diperlukan oleh kantor pusat Wire Plastic Product Incorporation (WPP) dalam sistem pelaporan Grup yang berbasis intranet Systems, Applications and Products Business Objects Financial Consolidation (SAP-BFC).

Anak Perusahaan sebagai unit pelaporan, dituntut untuk mematuhi standar kebijakan grup, menyiapkan laporan Flash di Business Objects Financial Consolidation (BFC) secara bulanan, biasanya empat hari kerja setelah berakhirnya bulan. Flash terdiri dari sejumlah poin-poin penting Profit and Loss (P \& L), termasuk pendapatan, margin kotor, laba operasi dan PBIT, bersama dengan angkaangka untuk insentif, pesangon, ketentuan modal kerja dan bunga eksternal dan antar
(Hsu, 2013). Namun, hanya 25\% praktisi melaporkan bahwa ERP mereka sepenuhnya terintegrasi. Sebagian besar (45\%) ERP terintegrasi hanya sebagian, dan $20 \%$ peserta menyatakan bahwa mereka menggunakan sistem yang terpisah. Oleh karena itu, tampaknya masih banyak tantangan dalam tahapan dalam upaya mengintegrasikan proses dalam ERP. $45 \%$ responden juga mengungkapkan bahwa mereka menggunakan alat Business Intelligence dalam pelaporan keuangan, meskipun $80 \%$ dari mereka menggunakan Microsoft Excel. Dengan demikian, dapat disimpulkan bahwa Excel adalah alat yang paling populer untuk berlatih fungsi akuntansi dan menyajikan laporannya kepada para pemangku kepentingan.

Data di atas membentuk lingkungan di sekitar kerangka kerja dalam pengembangan dengan memasukkan strategi, Enterprise Resource Planner (ERP), Business Intelligence (BI) sebagai elemen penting dalam penerapan Time Driven Activity Based Costing (TD-ABC), Target Costing (TC), Just In Time Costing (JIT), Balanced Scorecard (BSC) dan lean accounting yang menghubungkan bersama.

perusahaan. Flash termasuk manajemen pelaporan Profit and Loss (P\&L). Sembilan hari kerja setelah akhir bulan, perusahaan diharuskan untuk melaporkan laporan laba dan rugi, neraca lengkap bersama dengan berbagai analisis pendukung termasuk pendapatan, penundaan piutang oleh klien, headcounts, dan informasi arus kas.

Pada unit pelaporan yang sebenarnya memberikan perkiraan pendapatan yang direvisi untuk mengikuti tiga bulan dan pengingat tahun ini.

- Forecast: Setelah akhir kuartal, dalam waktu 12 hari berikutnya, perusahaan diharuskan mengirimkan pembaruan bulan demi bulan dari hasil survei mereka untuk tahun ini, termasuk manajemen P \& $\mathrm{L}$, sumber daya dan perkiraan belanja modal.

- Budget: Juga unit operasi menyerahkan anggaran di BFC ke WPP pada awal November sehubungan dengan tahun keuangan berikutnya. Ini akan mencakup anggaran bulanan $\mathrm{P} \& \mathrm{~L}$ per bulan, dan analisis pendukung, serta data tambahan, 
termasuk belanja modal dan informasi real yang rinci. Dalam mempersiapkan anggaran, kelompok operasi WPP harus memperhatikan sasaran keuangan Grup yang meliputi pertumbuhan laba operasi, peningkatan marjin operasi, biaya staf terhadap pendapatan, pertumbuhan gaji tidak lebih dari 3/4 dari pertumbuhan pendapatan. WPP menetapkan tujuan untuk setiap kelompok operasi yang membahas target keseluruhan berikut.

- Variance: Dalam setiap pengiriman laporan, diperlukan catatan untuk menjelaskan variasi utama pada setiap topik P \& L. Ini adalah aspek penting dari pelaporan yang efektif dan efisien untuk WPP. Catatan tersebut harus terdiri dari rangkuman variasi yang memadai untuk WPP dan kantor pusat untuk memahami penyebab terjadinya variasi utama.

- Corporate responsibility reporting: Perusahaan harus melaporkan paket pelaporan tanggung jawab perusahaan (Corporate responsibility / CR) di BFC dalam 30 hari sejak akhir kuartal. Pengajuan triwulan ini membutuhkan berbagai data tentang masalah tanggung jawab sosial perusahaan, termasuk penggunaan energi, keragaman etnis, pekerjaan, kepatuhan dengan standar pemasaran.

- Client profitability: Selanjutnya, analisis profitabilitas pelanggan secara triwulanan diserahkan dalam 30 hari setelah akhir kuartal.

- Overhead: Sebagai bagian dari proses penganggaran, kelompok operasi menetapkan tingkat alokasi overhead yang dianggarkan untuk tahun yang akan datang.

- Balance sheet analysis: Setelah setiap akhir kuartal, pelaporan Grup WPP melakukan tinjauan analitis dari keterangan neraca lainnya, khususnya akun yang mendapat catatan "unverified". Kualitas dan ketepatan waktu penjelasan dari perusahaan sangat penting untuk proses ini, yang juga merupakan kunci dari alat audit.

Prosedur sebagaimana disebutkan di atas diikuti oleh Perusahaan untuk memenuhi persyaratan pelaporan internal dalam proses yang lebih divisualisasikan yang disajikan di bawah ini pada gambar 1:

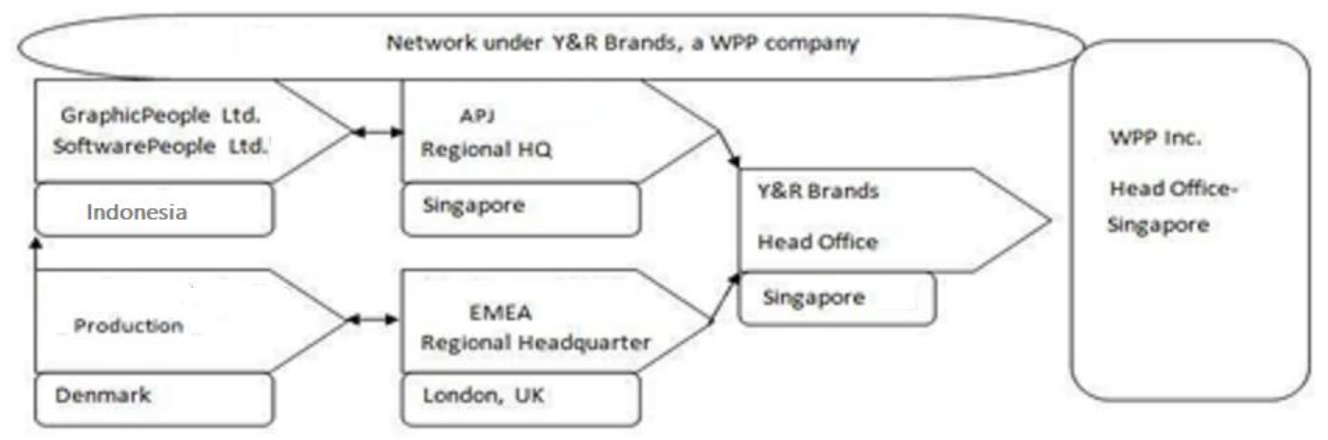

Gambar 1: Hubungan Pelaporan dalam Jaringan Perusahan Yang Diteliti

\section{Implikasi teknologi informasi}

Hasil penelitian ini menjelaskan bahwa perusahaan memiliki persyaratan pelaporan eksternal untuk memenuhi kebutuhan pelanggan dengan menggunakan sistem manajemen proyek, yang dinamakan 'Workbook' untuk menangani data terkait work order dari perusahaan. Perusahaan yang diteliti juga menggunakan, alat intelijen bisnis yang disebut Tableau digunakan untuk tujuan pelaporan keuangan klien. Semua penyimpanan data produksi di gudang data berbasis cloud. File-file produksi dikirim ke server ke pusat. Basis data ini juga disimpan di server cloud Amazon pada saat yang bersamaan.

\section{Implikasi Target Costing}

Implikasi target costing dalam pengujian kerangka kerja pertama dimulai tepat sebelum tahun dimulai, karena anggaran untuk tahun 
berikutnya dimulai dari bulan November setiap tahunnya. Kemudian, berdasarkan informasi yang relevan, seperti tujuan perusahaan, persyaratan pelanggan, dan volume penjualan, perusahaan dapat menentukan biaya yang diijinkan dan memutuskan biaya pendekatan apa yang harus dialokasikan. Di perusahaan yang diteliti, anggaran disusun untuk tahun mendatang dengan mengidentifikasi kebutuhan pelanggan. Negosiasi dan diskusi yang intens dengan klien berlangsung sehingga perusahaan dapat meramalkan angka penjualan secara lebih terperinci. Berdasarkan persyaratan pelanggan dan anggaran penjualan, perusahaan menyiapkan anggaran tenaga kerja dan menentukan peran yang berbeda. Dalam proses ini, penetapan biaya berdasarkan aktivitas diterapkan untuk menghitung tingkat per jam dari peran yang berbeda.

Tabel 1: Target laporan penetapan biaya

Target Costing Report

\begin{tabular}{|c|c|c|c|c|}
\hline \multirow{2}{*}{ Particulars } & \multicolumn{3}{|c|}{ VALUE STREAM } & \multirow{2}{*}{$\begin{array}{l}\text { TOTAL } \\
\text { Amount }\end{array}$} \\
\hline & GP & SP & AdPeople & \\
\hline \multirow{2}{*}{ Budgeted r evenue (Yearly) } & 480,000 & 120,000 & $1,032,000$ & $1,632,000$ \\
\hline & & & & - \\
\hline \multirow[t]{2}{*}{ Margin ( $10 \%$ of revenue) } & 48,000 & 12,000 & 103,200 & 163,200 \\
\hline & & & & - \\
\hline \multirow[t]{2}{*}{ TARGET COST (for the year) } & 432,000 & 108,000 & 928,800 & $1,468,800$ \\
\hline & & & & - \\
\hline \multirow[t]{2}{*}{ Numbers of headcount } & 150 & 30 & 30 & 210 \\
\hline & & & & - \\
\hline HEAD COUNT SPECIFICATION & & & & - \\
\hline Creative & 0 & 0 & 8 & 8 \\
\hline Production & 129 & 22 & 5 & 156 \\
\hline Quality Check & 9 & 6 & 2 & 17 \\
\hline \multirow[t]{2}{*}{ Project Management } & 12 & 2 & 15 & 29 \\
\hline & & & & - \\
\hline \multicolumn{5}{|l|}{ RATE per min ute as per TD/ABC } \\
\hline Creative & - & - & 0.11 & 0.11 \\
\hline Production & 0.026 & 0.032 & 0.10 & 0.15 \\
\hline Quality Check & 0.026 & 0.034 & 0.10 & 0.16 \\
\hline Project Management & 0.033 & 0.045 & 0.10 & 0.18 \\
\hline
\end{tabular}

Target biaya berkontribusi dalam mengoptimalkan pemanfaatan sumber daya dengan mencari cara terbaik untuk mengurangi biaya penggunaan sumber daya dengan cara berkoordinasi dengan pemasok, menciptakan symbiosis mutualisme antarorganisasi dalam value chain. Selain itu, target biaya dapat memfasilitasi penerapan lean accounting, dengan fokus pada penciptaan nilai bagi konsumen dengan peningkatan fungsionalitas dan kualitas produk atau layanan.

\section{Penerapan Time Driven-ABC}

Dalam penelitian ini, perusahaan yang diteliti adalah suatu perusahaan yang memiliki sumber daya manusia yang sangat massif dan intensif, dimana biaya overhead dialokasikan berdasarkan pada jam kapasitas sumber daya yang dalam posisi sebagai ujung tombak pemasaran perusahaan. Jam kapasitas standar per hari adalah 7,5 jam sehingga jam mingguan adalah 37,5 jam, sehingga jam bulanan adalah 150 jam dan jam tahunan adalah 1800 per karyawan. Oleh karena itu, dapat diketahui menit per tahun per karyawan full-time adalah 108.000 menit. Perbedaan antara Time Driven- ABC dan praktik ditemukan ketika diamati bahwa waktu dicatat sebagai jam, tidak sebagai menit. Waktu 
proses harus diperkirakan untuk setiap kegiatan dalam alur kerja. Dari sudut pandang teoritis, (Monroy, Nasiri, \& Peláez, 2014) menyatakan bahwa TD-ABC menganalisis kapasitas setiap proses dan biaya untuk kinerja mereka, yang membuatnya dekat dengan prinsip-prinsip lean accounting dengan meletakkan biaya dalam value stream-nya.

Tabel 2: Pernyataan TD-ABC

TD ABC statement of cost per role per munits

\begin{tabular}{|l|r|r|r|r|r|}
\hline Activities & $\begin{array}{l}\text { Cost Driver } \\
\text { (Quantity) }\end{array}$ & Unit time & Total Time & $\begin{array}{l}\text { Capacity cost } \\
\text { Rate }\end{array}$ & $\begin{array}{l}\text { Total Cost } \\
\text { Assigned }\end{array}$ \\
\hline \hline Creative & 8 & 108,000 & 864,000 & 0.07 & 56,160 \\
\hline Production & 5 & 108,000 & 540,000 & 0.06 & 29,700 \\
\hline Quality Check & 2 & 108,000 & 216,000 & 0.06 & 11,880 \\
\hline Order handeling and Delivery & 15 & 108,000 & $1,620,000$ & 0.06 & 99,540 \\
\hline Purchase from Graphic People & 150 & 108,000 & $16,200,000$ & 0.03 & 480,000 \\
\hline Purchase from SoftwarePeople & 30 & 108,000 & $3,240,000$ & 0.04 & 120,000 \\
\hline Indirect costs (fixed production overhead) & 30 & 108,000 & $3,240,000$ & 0.04 & 131,520 \\
\hline \hline Total capacity used & & & $3,240,000$ & & 928,800 \\
\hline Total ca pacity Supplied & $\mathbf{3 0}$ & 97,200 & $2,916,000$ & 0.04 & 915,648 \\
\hline Unused capacity & & & 324,000 & & 13,152 \\
\hline
\end{tabular}

TD-ABC berkontribusi dalam pengoptimalan kapasitas sumber daya sebagai kemampuan sumber daya yang dipantau dalam pelaksanaan kegiatan dalam proses pada aktual dengan tingkat pemanfaatan dibandingkan dengan anggaran di tingkat unit serta di tingkat aliran nilai (Monroy et al., 2014). Oleh karena itu, manajemen dapat mendiagnosis alasan kapasitas yang tidak digunakan dalam peta proses dan mengambil tindakan perbaikan untuk mengurangi pemborosan sumber daya. Kaplan (2014) berpendapat bahwa alat ini dapat secara langsung memperhitungkan sebagian besar biaya tidak langsung seperti depresiasi peralatan, fasilitas, serta biaya dukungan seperti biaya pelayanan pelanggan. TD-ABC dapat dihubungkan dengan JIT karena pada tahap ini setiap waktu proses dihitung, dapat menerapkan sistem 'pull' dengan menghitung waktu tunggu dalam rantai pasokan.

\section{Penerapan Just in Time}

Dalam perspektif Jepang, just in time (JIT) dianggap sebagai sistem manajemen produksi di mana bahan, orang dan peralatan saling terkait. Dalam kerangka teoritis, JIT dipertimbangkan sebagai teknik kontrol manajemen. JIT melakukan serangkaian program dengan filosofi, di mana operasi berjalan berdasarkan permintaan pelanggan mengurangi limbah dan meningkatkan kecepatan sambal tetap mempertahankan kualitas yang mengarah kepada pengoptimalan pemanfaatan sumber daya di seluruh proses secara real time. Peneliti menemukan hasil sebagai berikut:

- Perusahaan yang diteliti menghasilkan layanan, materi dan dimana inventory diminimalkan dengan pendekatan JIT. Masukan utama ke dalam proses penciptaan nilai adalah sumber daya manusia. Sejalan dengan prinsip JIT, karyawan front-line ditugaskan sesuai dengan perkiraan permintaan pelanggan.

- Kebutuhan pelanggan memicu kebutuhan sumber daya yang akan mempengaruhi anggaran perusahaan. Pengiriman tepat waktu dipastikan dengan server cloud. Perusahaan mengembangkan sampel media dan mengunggahnya ke server cloud, sehingga anak perusahaan yang bergerak pada bidang desain grafis dapat mengunduh media file, membuat rencana produksi dan menjadwalkan pengiriman yang sesuai dengan permintaan. Dengan demikian, JIT 
memfasilitasi visualisasi real-time dari adanya pesanan di tingkat retail atau departemen produksi dan memberikan peningkatan keterlibatan dan pengawasan dalam proses manufaktur. Kualitas ini terus-menerus diperiksa oleh Quality Engineer dan optimalisasi pemanfaatan sumber daya dievaluasi oleh manajer proyek dan dan dilaporkan kepada klien.

- Waktu proses rata-rata di perusahaan produsen, keterlibatan karyawan, pengiriman yang tepat waktu, dan standar kualitas dihitung dan diimplementasikan untuk menerapkan peningkatan yang berkelanjutan, dimana hal tersebut dapat dilihat dalam laporan pemantauan JIT. Informasi ini dapat dirangkum dalam Balanced Scorecard, dan akhirnya ditampilkan dalam kartu Box Score lean accounting .

Tabel 3: Just in time statement

\begin{tabular}{|c|c|c|c|c|c|c|c|c|c|}
\hline \multirow{2}{*}{$\begin{array}{l}\text { Just In Time (JIT } \\
\text { Customer Order }\end{array}$} & \multirow{2}{*}{$\begin{array}{l}\text { Year to dat } \\
\text { Customer }\end{array}$} & \multirow{2}{*}{$\begin{array}{l}\text { te (YTD) } \\
\text { Job Name }\end{array}$} & \multirow[b]{2}{*}{$\begin{array}{l}\text { Quantity } \\
\text { Ordered }\end{array}$} & \multicolumn{2}{|c|}{\begin{tabular}{|l|l|l} 
Estimated & Actual \\
\end{tabular}} & & \multirow[b]{2}{*}{$\begin{array}{l}\text { Delivery } \\
\text { status }\end{array}$} & \multirow[b]{2}{*}{ Quality } & \multirow[b]{2}{*}{ Stage } \\
\hline & & & & \begin{tabular}{|l|} 
Process \\
time \\
(Days) \\
\end{tabular} & \begin{tabular}{|l|} 
Actual \\
production \\
time (Days)
\end{tabular} & Capacity usage & & & \\
\hline A & 1 & Software & 80 & \begin{tabular}{l|r} 
& 80 \\
\end{tabular} & 16 & $20 \%$ & & 1st Pass & Order received \\
\hline B & $\mathrm{J}$ & Software & 250 & 250 & 120 & $\square$ & & 1st Pass & Creative \\
\hline C & $T$ & Web & 65 & 52 & 51 & $98 \%$ & On-time & 2nd Pass & Delivered \\
\hline$x$ & D & Web & 500 & 400 & 586 & $147 \%$ & On-time & 1st Pass & Delivered \\
\hline$Y$ & D & Graphic & 60 & 28 & 34 & $121 \%$ & Late & 2nd Pass & Quality \\
\hline$z$ & D & Web & 100 & 80 & 80 & $100 \%$ & On-time & 1st Pass & Invoiced \\
\hline Total & & & 1055 & 890 & 886 & & & & \\
\hline
\end{tabular}

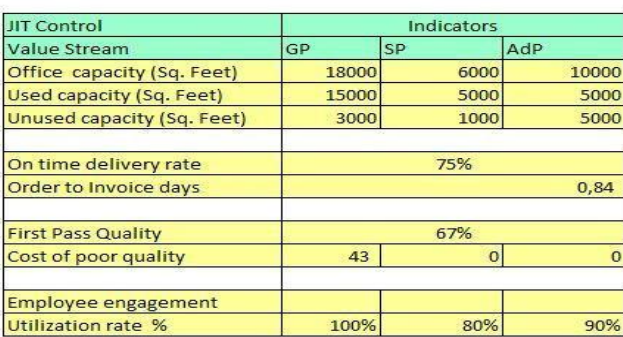

Penerapan Income Statement yang berbasis Lean Accounting

Manajemen lean, sampai taraf tertentu, dipraktekkan di perusahaan yang diteliti tanpa memiliki hubungan yang sistematis dengan TC, TD-ABC dan BSC. $\mathrm{CEO}$ perusahaan menjelaskan analisis value stream dilakukan dengan menggunakan alat bussines intelegent yang disebut 'Tableau'. Filosofi JIT tercermin dalam platform berbasis cloud "Dell-share" yang menyimpan knowledge assets dan memfokuskan diri pada kepuasan pelanggan serta ketepatan waktu pengiriman. Implikasi parsial dari TD-ABC ditemukan sebagai pemanfaatan kapasitas dimonitor mengambil data dari work-book. Setelah menerapkan akuntansi lean, mengintegrasikan TD-ABC, TC, JIT dan BSC dalam konteks perusahaan yang diteliti, ditemukan bahwa laporan laba rugi dapat menyajikan peningkatan visibilitas penggunaan sumber daya melalui value chain dalam tabel sederhana.

Tabel 4: Weekly lean accounting income statement 


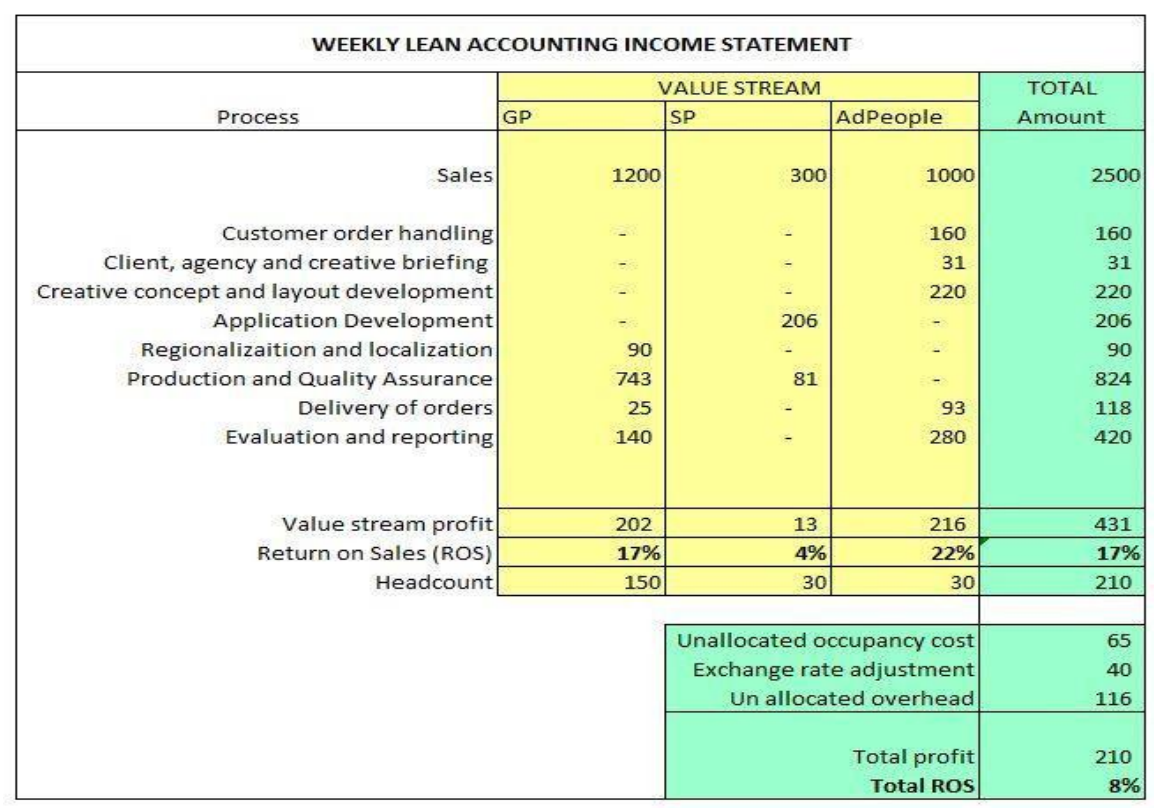

Dalam pengujian ini kerangka balanced scorecard digunakan untuk memetakan proses ini. Selanjutnya, tujuan aliran nilai dipantau melalui pengukuran kinerja pada laporan laba rugi lean accounting yang mendorong peningkatan yang berkelanjutan.

\section{Penerapan Balanced Scorecard}

Balanced scorecard menghasilkan indikator pengukuran kinerja dari proses akuntansi lean. Sebagian besar pengukuran dapat ditemukan dalam Box Score laporan lean accounting yang mengukur dan memetakan aliran nilai. Selain itu, nilai kotak adalah output JIT, TC, $\mathrm{TD} / \mathrm{ABC}$ yang membenarkan integrasi balanced scorecard dalam akuntansi lean. Aplikasi lain yang mungkin dari BSC adalah untuk mengklarifikasi strategi dan mengidentifikasi inisiatif penting ketika mengalokasikan sumber daya dan menetapkan prioritas (Giannopoulos et al., 2013). Dalam perusahaan yang diteliti, BSC digunakan untuk membuat strategi di seluruh proses, sehingga prioritas strategis dapat dikaitkan dengan berbagai aspek dimensi kinerja dalam rantai nilai. Ketika balanced scorecard diimplementasikan bersama dengan alat lain, pemetaan strategi, pengambilan keputusan dan visibilitas kinerja value stream akan lebih lancar. Selain itu, inisiatif peningkatan untuk mencapai tujuan strategis untuk mengoptimalkan pemanfaatan sumber daya juga akan lebih mudah. Oleh karena itu, indikator memberdayakan manajemen tindakan apa yang harus diambil untuk menciptakan nilai bagi pelanggan dan karyawan. Namun, dalam konteks perusahaan yang diteliti, output dari proses akuntansi tradisional juga perlu diintegrasikan untuk memetakan kinerja strategis dalam fledge penuh. Selain itu, beberapa indikator kinerja utama (KPI) adalah hasil dari proses departemen sumber daya manusia seperti indeks keterlibatan karyawan dan hasil laporan dari departemen pemasaran dalam kasus BSC menggabungkan indeks kepuasan pelanggan. Namun, ketika semua modul rantai nilai diberlakukan di ERP, hasilnya akan masuk langsung di papan secara otomatis. Dalam hal ini, jika ada yang salah, variasi dalam indikator memicu interaksi sehingga diskusi semakin intensif dan masalah diperbaiki dengan peningkatan koordinasi dan dialog di antara manajer dari berbagai departemen.

Tabel 5: Balanced scorecard 


\section{Owner \\ RISET \& JURNAL AKUNTANSI \\ e-ISSN : 2548-9224 \\ RISET \& JURNAL AKUNTANS

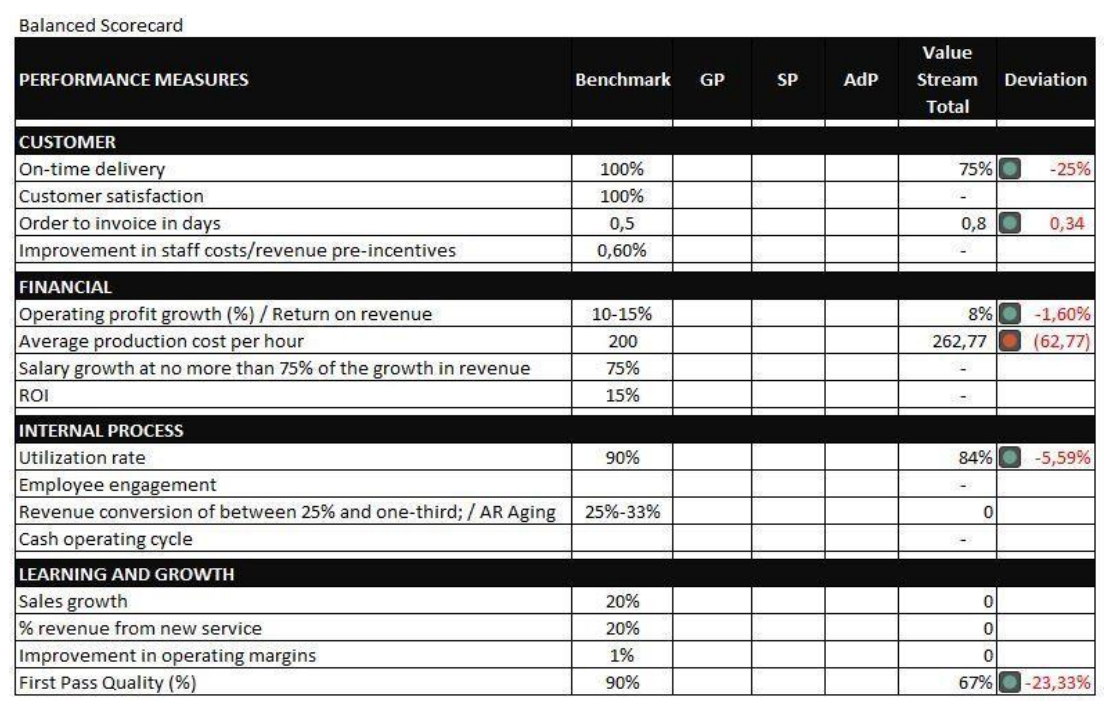

\section{Value Stream Box Score}

Box Score menyajikan operasional, kapasitas sumber daya dan ukuran keuangan dalam tiga bagian terpisah yang dianggap sebagai pendorong utama untuk optimalisasi nilai. Kita dapat mengasumsikan Box Score dapat memberdayakan manajemen dan karyawan untuk mengambil keputusan yang efektif untuk memperbaiki keadaan masa depan dari value stream untuk menciptakan nilai bagi pelanggan. Implementasi value stream box score dapat menjadi alat yang digunakan untuk membangun relasi antara operasional lapangan, laporan keuangan dan departemen akuntansi. Beberapa pengukuran operasional non-keuangan yang penting dari balanced scorecard dapat dikaitkan dengan penggunaan Box Score. Box Score dapat diposting di lantai produksi melalui layar LED yang terstruktur dalam bingkai untuk memotivasi timbulnya perilaku yang benar.

Laporan laba rugi lean accounting menghitung laba atas penjualan $17 \%$. Namun, dalam kasus ini perusahaan menghasilkan laba atas penjualan kembali sebesar $10 \%-20 \%$. Dengan demikian, Box Score menunjukkan tingkat perbedaan sebesar 3\%, yang merupakan tingkat optimasi yang ditargetkan untuk peningkatan yang direncanakan.

Tabel 6: Weekly box score for value stream mapping

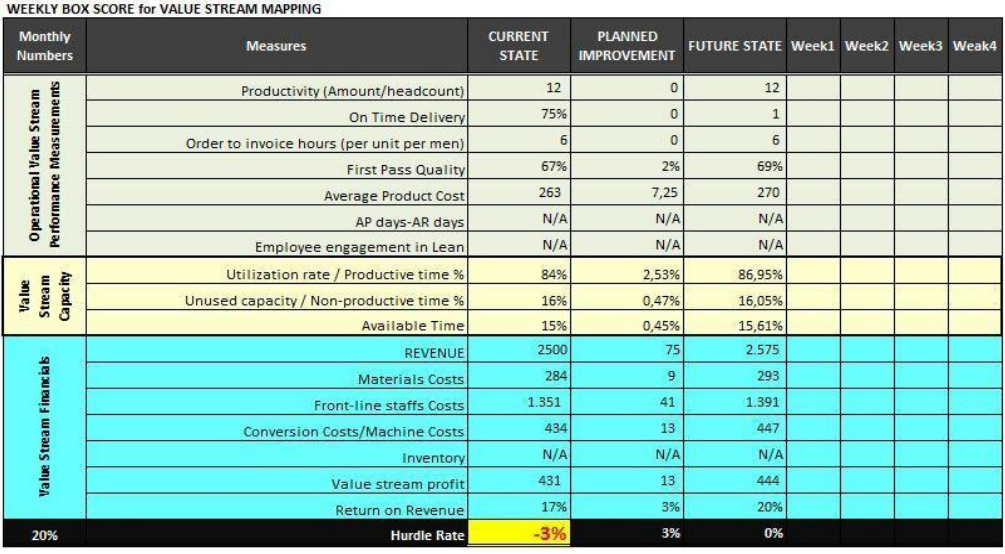

Selain itu, dengan menerapkan kerangka kerja, penelitian ini mendapatkan hasil untuk studi kasus pada perusahaan yang diteliti, sebagai berikut: 
- Karyawan yang terlatih cenderung akan membuat pelanggan lebih puas dengan layanan dan produk yang akan mengarah pada peningkatan penjualan dan peningkatan pangsa pasar. Pelatihan tambahan akan mendorong karyawan untuk meningkatkan efektivitas kinerja dan merespon masalah dengan cepat.

- Standarisasi dan penyederhanaan. Karyawan yang berpengalaman dan proaktif sangat penting dalam standardisasi dan penyederhanaan pekerjaan yang dapat mempengaruhi kualitas dan kecepatan, mengacu pada teknik JIT dan lean accounting (Monroy, Nasiri \& Peláez, 2012; Filippini \& Forza, 2016). Oleh karena itu, perusahaan dapat mengambil manfaat dari peningkatan retensi karyawan dan mengurangi tingkat turnover karyawan.

- Perusahaan dapat memperkenalkan Identifikasi Data Elektronik (EDI) dalam memperkuat pendekatan JIT untuk mengotomatisasi penerimaan lingkup pekerjaan, pesanan pembelian, pengarahan, dan instruksi pembayaran dari pelanggan. EDI akan memastikan semua itu tepat waktu dan dengan cara yang efisien untuk bertukar informasi terkait pesanan pembelian ke pemasok, penerimaan faktur dan pembayaran ke vendor.

- $\quad$ Standarisasi Lead time. Perusahaan dapat mengukur lead time rantai nilai dengan pengamatan yang cermat dengan ukuran metrik untuk menentukan berapa banyak waktu yang dibutuhkan pada setiap aktivitas dalam memproduksi dan memberikan layanan yang berbeda berdasarkan ukuran dengan mempertimbangkan tingkat kompleksitas produk. Kaplan (2014) dan Monroy, Nasiri dan Peláez (2012) sepakat bahwa TD-ABC, lean accounting dan pendekatan JIT menekankan biaya waktu yang terdapat dalam setiap kegiatan.

- Ukuran kinerja. Dengan bantuan survei pemasaran, perusahaan dapat membandingkan waktu, kualitas, dan kecepatan per layanan yang berbeda dengan pesaing dan menetapkan patokan untuk pemantauan. Perbandingan TC dan BSC juga dapat diterapkan untuk membandingkan biaya inti dalam perusahaan jasa dan untuk menetapkan biaya, kualitas dan waktu terkait pengembangan BSC.

\section{Optimalisasi pemanfaatan kapasitas sumber daya}

Hal ini diamati bahwa ada hubungan yang halus antara TC + TDABC + JIT + BSC, yang mengikuti melalui rantai nilai, membuat prinsip-prinsip lean accounting menjadi ada dalam praktek. Laporan laba rugi akuntansi lean memvisualisasikan kinerja proses di sekitar value stream yang menunjukkan laba atas penjualan. Pengembalian atas penjualan ini diringkas dalam Box Score yang mencerminkan pendorong utama inisiatif peningkatan yang perlu dipertimbangkan oleh manajemen jika ada tingkat rintangan negatif. Tingkat rintangan menunjukkan persentase pengembalian pendapatan yang perlu dicapai organisasi untuk mencocokkan margin yang ditargetkan. Itu mungkin ketika limbah diminimalkan, biaya pengerjaan ulang dikurangi, dengan peningkatan keterlibatan karyawan, pengiriman tepat waktu, kepuasan pelanggan.

Perubahan teknik akuntansi manajemen harus sejalan dengan perubahan pada proses manufaktur. Pengubahan proses produksi secara radikal tanpa mengubah sistem kontrol manajemen menciptakan ketidaksesuaian tujuan, inkonsistensi dalam evaluasi kinerja dan perilaku disfungsional. Jika organisasi mengadopsi manajemen lean dan filosofi lean manufacturing yang memfokuskan pelanggan, memberdayakan karyawan, mengurangi inventaris, dll. Kerangka kerja yang diusulkan $\mathrm{TC}+\mathrm{TDABC}+\mathrm{JIT}+\mathrm{BSC}$ yang terintegrasi yang akan dapat memberikan hasil yang bermanfaat. Dan, itu harus didukung oleh kustomisasi ERP sehingga sistem dapat menangkap aktivitas utama dan dukungan di seluruh rantai nilai yang memanfaatkan teknologi informasi melalui otomatisasi dan integrasi. 


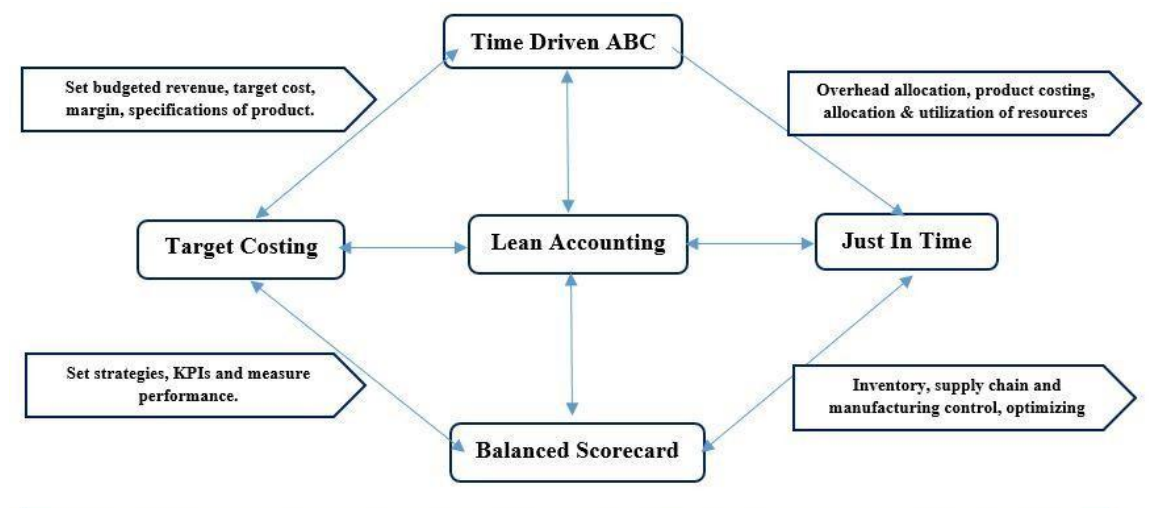

Integrated management accounting package; for optimizing utilization of resources across the value chain

Gambar 2: Penerapan lean accounting integrating TC+TDABC+JIT+BSC

\section{IMPLIKASI}

\section{MANAJEMEN}

Serangkaian nilai yang berfluktuasi dari 2005 hingga 2016 telah menyebabkan penurunan dalam pendapatan, jumlah USD 11

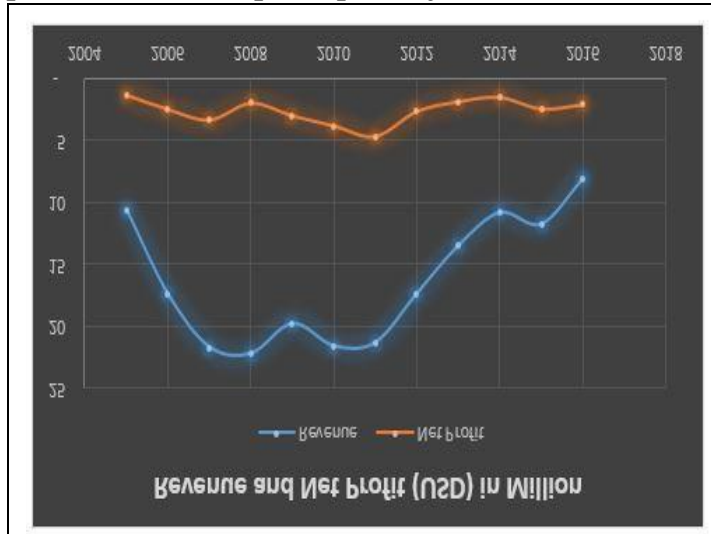

juta dilaporkan pada tahun 2005 ketika jumlah dalam USD 8 juta dilaporkan pada tahun 2016

Gambar 3: Grafik yang menunjukkan implikasi MCS terhadap tren pendapatan, laba, dan jumlah pegawai dari Perusahaan yang diteliti

Ilustrasi di atas menunjukkan tingkat pendapatan selama 12 tahun dengan mulai dari, termasuk hubungan antar jumlah pegawai dan laba. Pendapatan dan jumlah pegawai hampir mencapai arah yang sama. Di sisi lain, garis laba relatif datar dibandingkan dengan garis kurva pendapatan. Alasannya adalah bahwa perumusan strategi, akuntansi manajemen dan keputusan keuangan perusahaan dikendalikan oleh kantor pusat. Fokusnya terutama pada kontrol ketat pada garis dasar, memperkenalkan praktik-praktik baru dalam persyaratan pelaporan terutama menggunakan kontrol cybernetic yang memastikan stabilitas margin laba meskipun pendapatan dan jumlah pegawai menurun tajam. Selain itu, selama waktu manajemen memperoleh efisiensi dan beradaptasi secara strategis terhadap perubahan struktur bisnis, memasang teknologi inovatif dapat meningkatkan kehandalan operasi dan dapat terus meningkatkan efektivitas operasional. Dengan mengendalikan biaya, perusahaan dapat berkontribusi pada kebutuhan klien untuk tetap dalam lingkup anggaran mereka dan tingkat yang disetujui.

Sebagai contoh, penetapan target biaya menggunakan tarif per unit produk atau layanan yang dihitung dengan $A B C$ based time driven yang berkontribusi sebagai dasar untuk menyusun anggaran mengikuti prioritas strategis dan persyaratan pelanggan. 
Selanjutnya, prinsip-prinsip JIT dapat tercermin dalam mengendalikan rantai pasokan dan manajemen manufaktur. Siklus ini dapat digunakan untuk memantau lead time dalam menentukan persediaan, waktu pengiriman dan pengiriman tepat waktu kepada pelanggan. Pengukuran non-keuangan terkait dengan kualitas, Balanced scorecard keterlibatan karyawan juga dapat dihubungkan dalam pemantauan JIT.

\section{ANALISA}

Penelitian ini mengungkapkan bahwa terlepas dari kritik keras terhadap akuntansi tradisional oleh akademisi (Kaplan dan Anderson, 2013), para praktisi masih bergantung pada sistem akuntansi konvensional. Itu karena database akuntansi atau General Log book didasarkan pada persyaratan peraturan keuangan, yang menghasilkan laporan keuangan yang bertujuan bagi penggunanya terutama para pemegang saham dan instansi pemerintah. Secara bersamaan, database yang sama digunakan untuk sistem manajemen akuntansi, sehingga feedback keputusan untuk membuat permintaan dalam optimalisasi kapasitas sumber daya melalui penciptaan value chain dilakukan oleh manajemen dan karyawan (Hsu, 2013).

JIT memberdayakan manajemen dan staf front line dimana pada saat yang sama dapat menampilkan tindakan non-keuangan yang berorientasi pada masa depan. Sedangkan Lean Accounting menghubungkan TD-ABC dapat menghasilkan ukuran keuangan aktual. Laporan pendapatan lean accounting dan balanced scorecard dapat memvisualisasikan kinerja value stream secara keseluruhan yang menghubungkan prioritas strategis yang dapat memfasilitasi pengambilan tindakan perbaikan untuk mencapai konsumsi sumber daya yang optimal. Hubungan sistematis antara TC, TD-ABC, JIT, BSC dan lean accounting tersebut dapat digambarkan pada table di bawah ini:

Tabel 7: The integration of management accounting techniques within cybernetic control

\begin{tabular}{|l|l|l|l|}
\hline \multicolumn{3}{|c|}{ Cybernetic Control } \\
\hline Budgets & Financial & Non Financial & Hybrid Measurement \\
Target costing & Measurement System & Measurement System & System \\
TD-ABC & Lean accounting & Just in time control & Balanced Scorecard \\
& income statements & report & Value stream Box \\
& TD-ABC & & Score \\
\hline
\end{tabular}

Source: Adapted of framework of Medeiros, Santana \& Guimarães (2017)

Konsep dasar diperkirakan bahwa nilai pelanggan dibuat bersamaan dengan mengoptimalkan pemanfaatan sumber daya, maka value stream akan secara otomatis menciptakan nilai bagi para pemangku kepentingan lainnya yang menjadi perhatian seiring dengan peningkatan dari waktu ke waktu (Medeiros, Santana \& Guimarães, 2017). Penggunaan terintegrasi alat akuntansi manajemen modern ditekankan karena hal ini akan secara sistematis memproses data kinerja rantai nilai dari penetapan biaya produk ke analisis keuntungan aliran nilai dan profitabilitas pelanggan. Kerangka kerja ini tidak mengesampingkan sistem akuntansi tradisional karena perusahaan perlu menyiapkan laporan hukum dan memenuhi persyaratan pelaporan untuk tujuan eksternal. Kerangka penggunaan terintegrasi teknik akuntansi modern akan mencari data keuangan dan non-keuangan tambahan berdasarkan tujuan strategis yang cukup fleksibel untuk menyesuaikan ERP yang ada.

Temuan ini menyarankan penerapan sistem baru sebagai pendamping sistem akuntansi tradisional. Masalahnya adalah bahwa data proses tambahan akan memberdayakan controller untuk menganalisis kinerja value stream, profitabilitas pelanggan, profitabilitas produk, indeks kinerja utama untuk mencapai tujuan strategis untuk mengoptimalkan penggunaan kapasitas sumber daya yang berkoordinasi erat dengan $\mathrm{R} \& \mathrm{D}$, operasi dan manajer pemasaran. Efektivitas dan efisiensi kerangka yang diusulkan tergantung pada strategi organisasi, arti-penting pemangku kepentingan, manajemen risiko, otomatisasi dan integrasi yang ditingkatkan, kapasitas 
pengambilan keputusan dan pendekatan pemikiran sistem di sekitar sistem pengendalian manajemen (Hsu, 2013).

Kerangka teoritis yang diusulkan pada penelitian ini tidak dapat mengesampingkan pentingnya akuntansi tradisional, karena perusahaan harus menyiapkan laporan keuangan eksternal wajib dan mengikuti standar dan kepatuhan yang ditetapkan untuk menyiapkan laporan keuangan. Selain itu, upaya untuk mengimplementasikan kerangka ini dalam organisasi layanan kecil dengan basis pelanggan kecil dan bauran produk yang solid mungkin tidak relevan karena memerlukan upaya tambahan. Lebih jauh lagi, tanpa integrasi dan otomatisasi alat-alat akuntansi manajemen kontemporer itu dapat menjadi lebih mahal dan berlebihan, dengan demikian praktik-praktik itu mungkin akhirnya menjadi tak berguna.

Aplikasi gabungan dari metode modern telah memungkinkan untuk menempatkan efek sinergi dalam menyelesaikan distorsi akuntansi tradisional. Selain itu, penggunaan terintegrasi dari teknik-teknik ini memfasilitasi dalam merancang konstruksi akuntansi ramping.

Akuntansi manajemen yang berkembang di Jepang menetapkan dasar untuk lean manufacturing melalui TPS yang menggabungkan target biaya dan teknik manufaktur tepat waktu di tahun 1980-an. Namun, perkembangan populer di AS, untuk contoh $\mathrm{ABC}$ dan balanced scorecard dianggap tidak kompatibel dengan lean accounting. Terlepas dari kenyataan, dengan versi modifikasi $A B C$ untuk munculnya TDABC. Dalam penelitian hubungan sistematis ditunjukkan dengan merancang kerangka kerja sistem akuntansi manajemen terpadu untuk menerapkan lean accounting, berdasarkan studi kasus tunggal yang memperluas kontrol cybernetic secara rinci.

\section{SIMPULAN}

Penelitian ini menunjukkan integrasi dan penerapan metode akuntansi manajemen dalam kasus proses perusahaan melalui pemahaman mendalam tentang konstruksi yang mendasari perkembangan itu dengan studi publikasi yang terkait dengan tema. Penelitian ini menafsirkan dan mengkategorikan hubungan antara metode akuntansi biaya ketika diterapkan dalam model lean production. Sistem akuntansi manajemen terintegrasi dalam kerangka menghubungkan JIT + TC + TDABC + BSC bersama-sama untuk membangun akuntansi ramping dalam sebuah paket. Studi ini juga menunjukkan efisiensi sistem akuntansi manajemen tergantung pada fleksibilitas menyesuaikan database dalam ERP sebagaimana yang disyaratkan oleh tujuan strategis organisasi yang menjadi perhatian. Teknik akuntansi manajemen terpadu dalam paket menunjukkan cara sistematis untuk menangkap kinerja rantai nilai dengan dukungan MCS. Pemanfaatan sumber daya dioptimalkan setelah konsep lean dalam akuntansi memaksimalkan nilai pelanggan dengan mengurangi limbah, lead time, inventaris dan menghilangkan aktivitas nonnilai tambah dan proses re-konfigurasi sebagai hasil dari inisiatif peningkatan berkelanjutan.

Kerangka kerja yang digarisbawahi dalam penelitian ini lebih relevan untuk organisasi ukuran menengah sampai besar, di mana proses produksi secara rinci adalah suatu kelaziman. Kerangka ini mungkin tidak berlaku untuk organisasi-organisasi yang tidak beroperasi di pasar persaingan sempurna. Jika perusahaan memiliki peran dominan (monopoli) di pasar yang memiliki kekuatan untuk menentukan harga dan mengendalikan pilihan (permintaan) pelanggan, maka kerangka yang diusulkan mungkin kurang efektif. Adopsi dari kerangka yang diberikan tergantung pada kebijaksanaan manajemen puncak dalam kelompok perusahaan dalam struktur birokrasi, hierarkis karena mereka memegang otoritas untuk merancang struktur sistem berdasarkan inisiatif strategis mereka. Namun demikian, seorang manajer atau pengontrol dari perusahaan cabang atau anak perusahaannya menerapkan kebijakan, prosedur, dan arahan dalam struktur organisasi top-down yang tidak memiliki kendali atas perancangan sistem kontrol manajemen, sistem akuntansi manajemen dan sistem pengukuran kinerja. Dengan demikian, jika operasi organisasi tidak mengikuti prinsip lean manufacturing dan lean management maka sistem akuntansi manajemen terintegrasi ini tidak akan memiliki relevansi. Sebaliknya 
mungkin menyebabkan ketidakcocokan tujuan dan perilaku disfungsional dalam departemen lintas fungsional.

Sebagian besar penelitian berhubungan dengan akuntansi manajemen, atau akuntansi biaya dan menganalisis keunggulan perkembangan modern semata-mata dalam membandingkan dengan sistem tradisional yang menunjukkan kemungkinan cara untuk pengurangan biaya atau mengidentifikasi limbah atau proses rekonfigurasi. Ada ruang lingkup untuk pencarian lebih lanjut untuk mengeksplorasi hubungan prinsip lean dengan teknik akuntansi biaya dalam proses penciptaan nilai yang menghubungkan aliran nilai untuk memberikan wawasan yang berharga untuk peningkatan yang berkelanjutan, waktu dan manajemen proses. Akhirnya, penelitian ini dapat berfungsi sebagai sumber penelitian dan referensi untuk studi masa depan pada pelaporan yang terintegrasi dan lean accounting yang berkelanjutan.

\section{Referensi}

Al Maryani, M. A. H. \& Sadik, H. H. (2012). "Strategic management accounting techniques in Romanian Companies: some survey evidence". Procedia Economics and Finance, vol. 3, pp. 387-396.

Bryman, A. \& Bell, E. (2015). Business research methods. Oxford University Press, USA.

Egbunike, F. C., Ogbodo, O. C.Y. \& Onyali, C. I. (2014). "Utilizing Strategic Management Accounting Techniques (SMATs) for Sustainability Performance Measurement". Research Journal of Finance and Accounting, vol. 5, no. 13, pp. 140-153.

Filippini, R. \& Forza, C. (2016). “The Impact of the Just-in-Time Approach on Production System Performance: A Survey of Italian Industry". A Review and Outlook. In A Journey through Manufacturing and Supply Chain Strategy Research. Springer International Publishing, pp. 19-39.

Giannopoulos, G., Holt, A., Khansalar, E., \& Cleanthous, S. (2013). "The use of the balanced scorecard in small companies".
International Journal of Business and Management, vol. 8, no.14, pp. 1-22.

Hsu, P. F. (2013). "Integrating ERP and ebusiness: Resource complementarity in business value creation". Decision Support Systems, vol. 56, pp. 334-347.

Kaplan, R. S. (2014)." Improving value with TDABC". Healthcare Financial Management, vol. 68, no. 6, pp. 76-84.

Kaplan, R. \& Anderson, S. R. (2013). Timedriven activity-based costing: a simpler and more powerful path to higher profits. Harvard business press.

Nasiri , A. \& Peláez, M. Á. (2012). Activity Based Costing, Time-Driven Activity Based Costing and Lean Accounting: Differences Among Three Accounting Systems' Approach to Manufacturing. Annals of Industrial Engineering. Springer London, pp. 11-17.

Manzouri, M., Ab-Rahman, M.N., Che Mohd Zain, C.R. \& Jamsari, E.Z. (2014). "Increasing production and eliminating waste through lean tools and techniques for halal food companies". Sustainability, vol. 6, pp. 9179-9204.

Medeiros, H. D. S., Santana, A. F. B. \& Guimarães, L. D. S. (2017). The use of costing methods in lean manufacturing industries: a literature review. Gestão \& Produção.

Monroy, C. R., Nasiri , A. \& Peláez, M. Á. (2012). Activity Based Costing, TimeDriven Activity Based Costing and Lean Accounting: Differences Among Three Accounting Systems' Approach to Manufacturing. Annals of Industrial Engineering. Springer London, pp. 11-17.

Ofileanu, D. (2015). Lean Accounting - by when in Romania?. SEA: Practical Application of Science, vol, 3, no, 3.

Ramezani, A. R. \& Mahdloo, M. (2014). Lean and its Basic Components. Academic Journal of Research in Business \& Accounting, vol. 2, no. 4, pp. 36-45.

Romney, M. B. \& Steinbart, P. J. (2015). Accounting Information Systems (13th ed.). Pearson. 